\title{
MODEL PENGEMBANGAN SIKAP DAN AMAL KEAGAMAAN SANTRI DI PONDOK PESANTREN NURUL HAQ SEMURUP KERINCI JAMBI
}

\author{
Oleh: Masnur Alam \\ Dosen Filsafat Pendidikan Islam Jurusan Tarbiyah STAIN Kerinci \\ www.stain_krc@yahoo.co.id
}

\begin{abstract}
When viewed from the domain of educational objectives, attitudes and deeds are important factors to be achieved in the learning process. Religious attitude is positive or negative affective level toward an object, like it or not, accept it or reject it, the feeling of pleasure or displeasure. The religious deed refers to religious deeds or practices, or commonly called worship. Islamic students are not only required to know something, but they also must address, live and practice it. Islamic boarding school, as one of Islamic education institutions, acknowledges that the mastery of science and technology in the globalization era is very important, but the development of attitudes and religious deeds are much more important. One of the development efforts that must to be done is by offering a development model of attitudes and religious deeds in Nurul Haq Islamic Boarding School, Kerinci, Jambi.
\end{abstract}

Keywords: Model, Development of Attitudes, Religious Deeds, Islamic Students.

\begin{abstract}
Abstrak
Bila ditinjau dari domain tujuan pendidikan, sikap dan amal merupakan faktor penting yang ingin dicapai dalam proses pembelajaran. Sikap keagamaan merupakan tingkat afektif yang positif atau negatif terhadap suatu objek, suka atau tidak suka, menerima atau menolak, rasa senang atau tidak senang. Amal keagamaan merupakan perbuatan atau praktik keagamaan, atau biasa disebut dengan ibadah. Santri tidak saja dituntut untuk mengetahui sesuatu, tetapi juga harus menyikapi, menghayati serta mengamalkannya. Pesantren sebagai salah satu lembaga pendidikan Islam, penguasaan ilmu pengetahuan dan teknologi dalam era globalisasi sangat penting, tapi pengembangan sikap dan amal keagamaan jauh lebih penting. Salah satu upaya pengembangan yang harus dilakukan yaitu dengan menawarkan model pengembangan sikap dan amal keagamaan di Pondok Pesantren Nurul Haq Kerinci Jambi.
\end{abstract}

Kata Kunci: Model, pengembangan sikap, amal keagamaan, santri.

\section{PENDAHULUAN}

Dalam pendidikan Islam, sikap sangat erat hubungannya dengan keyakinan, kepercayaan, penghayatan, perasaan dan nilai, sikap sangat eratnya dengan kalbu (qalb). Pada qalb terdapat kepercayaan (iman), pengakuan atau membenarkan dengan yakin akan keesaan Allah. Pendidikan Barat bersumber pada nilai lahir, insani semata, seperti: nilai Materialis, Komunis, Kapitalis dan bersifat sekuler value free (bebas dari nilai), yang ditentukan orang yang menggunakan ilmu tersebut. Sedangkan dalam pendidikan Islam, bersumber pada al-Hadits, yaitu value full (sarat dengan nilai) yaitu nilai batin, nilai ilahi, nilai keagamaan yang berorientasi pada dosa dan pahala,

Naskah diterima 23 Oktober 2012. Revisi pertama 30 Oktober 2012. Revisi kedua 10 Nopember 2012. Revisi akhir 20 Nopemeber 2012 
halal haram, baik buruk, benar salah, boleh tidak boleh, yang sangat menekankan pada kepercayaan (belief). Amal berarti berbuat, mengerjakan, melakukan. Aspek amal merupakan aspek yang sangat penting, karena tidak sempurna iman seseorang kalau tidak direalisasi dengan amal. Sesuatu yang sudah diimani, dipahami, dihayati, dirasakan, maka harus diamalkan. Pengamalan dalam pendidikan Islam disebut ibadah. Dalam beribadah kepada Allah harus ta'at, (Q.S. An-Nur, 42: 54), semata-mata untuk Allah (Q.S. Al-An'am, 6: 162) dan sematamata untuk beribadat kepada Allah (Q.S. Al-Dzaari'at, 51: 56). Mentaati Allah berarti mengikuti dan mematuhi terhadap perintah dan menjauhi larangan.Nya.

Di Kabupaten Kerinci Provinsi Jambi terdapat beberapa pesantren, diantaranya pesantren Nurul Haq Semurup, merupakan pesantren yang masih tetap eksis, tetap survive, serta mampu bertahan, dapat melakukan adjusment dan readjusment di tengah arus globalisasi yang cukup deras dan penuh kompetensi. Di saat pondok pesantren lain gencar berkompetensi untuk meningkatkan prestasi santri melalui domain kognitif, akibatnya domain psychomotor dan domain afectif agak terabaikan. Namun uniknya pesantren Nurul Haq sangat konsern dan fokus dalam pengembangan domain tersebut, terutama dalam sikap keagamaan dan peningkatan amal keagamaan, namun domain kognitif tetap menjadi perhatian. Pesantren Nurul Haq ini mempopulerkan suatu ungkapan yaitu: "Ilmu tanpa amal laksana pohon tidak berbuah" Para lulusan pesantren Nurul Haq di harapkan memiliki "Ilmu yang amaliyah dan amal yang ilmiyah. ${ }^{1}$ Faktor inilah yang membuat pesantren Nurul Haq menjadi terkenal dan diminati oleh masyarakat sejak dulu sampai sekarang.

Pengembangan sikap dan amal keagamaan pada pesantren Nurul Haq dilaksa-

${ }^{1}$ Wawancara dengan Buya Darul Ulum, Pimpinan Pondok Pesantren Nurul Haq, tanggal 7 Juli 2012, di Semurup, Kerinci. nakan melalui bermacam usaha, di antaranya melalui pembelajaran, pengalaman, keteladanan, pembiasaan, targhib dan tarhib serta penciptaan suasaan keagamaan, sehingga murid/santri timbul keyakinan, kepercayaan terhadap agama dan menggapainya dengan positif, serta cenderung untuk menerima semua ajaran yang terdapat di dalamnya dan akhirnya timbul perasaan senang, ikhlas dan khusuk melaksanakannya. Dalam upaya pengembangan sikap dan amal keagamaan santri perlu diciptakan model yang dapat dijadikan pedoman dalam pengembangan sikap dan amal keagamaan tersebut. Model inilah yang akan ditawarkan dalam tulisan ini sehingga menjadi kontribusi bagi para pengembang sikap dan amal keagamaan dalam kehidupan santri.

\section{KERANGKA KONSEPTUAL}

\section{Pondok Pesantren}

PondokPesantrenadalah sebuah model khas pendidikan Islam tertua di Indonesia. Nurchalis Madjid ${ }^{2}$ mengungkapkan Pondok Pesantren tidak hanya identik dengan makna keislaman, tetapi juga mengandung makna keaslian Indonesia (Indigenous. Sebab lembaga serupa pesantren sebenarnya sudah ada masa Hindu Belanda mulai sejak munculnya masyarakat Islam di Nusantara pada abad ke-13.

Sebagai lembaga pendidikan Indigenous, Azumardi Azra ${ }^{3}$ berkomentar, pesantren memiliki akar sosio-historis yang cukup kuat, sehingga membuatnya mampu menduduki posisi yang relatif sentral dalam dunia keilmuan masyarakatnya, dan sekaligus bertahan di tengah-tengah gelombang perubahan. Taufik Abdullah ${ }^{4}$

\footnotetext{
${ }^{2}$ Nurcholis Madjid.1977. Bilik-bilik Pesantren. Jakarta: Paramadina, h.3

${ }^{3}$ Azyumardi Azra.2005. Esai-esai Intelektual Muslim dan Pendidikan Islam. Jakarta: Logos Wacana Ilmu, h.87

${ }^{4}$ Taufik Abdullah. 1983.Agama dan Perubahan Sosial. Jakarta: Rajawali, h.329
} 
mengatakan pesantren adalah tempat untuk membina manusia menjadi orang baik, dengan sistem asrama, artinya, para santri dan kyai hidup dalam lingkungan pendidikan yang ketat dengan disiplin. Karena potret pesantren pada dasarnya adalah asrama, dimana para santri tinggal bersama dan belajar ilmu-ilmu keagamaan dibawah bimbingan guru yang lebih dikenal dengan sebutan kyai (Ajengan di Jawa Barat, Tuan Guru di Lombok, Tengku di Aceh, Buya di Sumatera Barat).

Berdasarkan sejarah sejak awal berdirinya sampai pada akhir abad ke 20 mempunyai beberapa klasifikasi, yaitu: pertama, pesantren yang terdiri dari Masjid dan rumah kyai. Pesantren ini masih sangat sederhana dimana kyai menggunakan Masjid atau rumahnya sendiri untuk tempat mengajar santri dari daerah sekitar pesantren tersebut. Kedua, pesantren yang hanya terdiri dari Masjid, rumah kyai dan pondok atau asrama, pola ini telah dilengkapi pondok yang disediakan bagi para santri yang datang dari daerah lain. Ketiga, pesantren yang terdiri dari Masjid, rumah kyai, pondok atau asrama, dan Madrasah. Pola ini telah memakai klasikal, santri mendapat pelajaran di Madrasah. Disamping itu, juga belajar mengaji, mengikuti pengajaran yang diberikan oleh kyai di pondok. Keempat, pesantren yang telah berubah kelembagaannya yang terdiri dari Masjid, rumah kyai, pondok dan asrama, Madrasah dan tempat keterampilan. Pola ini dilengkapi dengan tempat-tempat keterampilan agar santri terampil dengan pekerjaan yang sesuai dengan sosial kemasyarakatan, seperti: pertanian, peternakan, jahit menjahit dan sebagainya. Kelima, seperti halnya pola keempat, ditambah adanya Universitas, gedung pertemuan, tempat olah raga dan sekolah umm. Pola ini pertanda lembaga pendidikan tersebut telah berkembang dan bisa dikatakan sebagai pesantren Modern. ${ }^{5}$

${ }^{5}$ Marwan Sarijo. 1980. Sejarah Pendidikan Pesantren di Indonesia. Jakarta: Dharma Bhakti, h.1011
Sejalan dengan klasifikasi tersebut Zamakhsyari Dhofier mengemukakan bahwa pesantren memiliki 5 elemen, yaitu pondok, masjid, pengajaran kitab Islam klasik, santri dan kyai. ${ }^{6}$

Uniknya semua perubahan itu sama sekali tidak mencerabut pesantren dari akar kulturalnya secara umum. Pesantren tetap memiliki fungsi sebagai: (1) lembaga pendidikan yang mentransfer ilmu-ilmu agama (tafaqquh fi aldin) dan nilai-nilai Islam (Islamic values), (2) lembaga keagamaan yang melakukan kontrol sosial (social control), dan (3) lembaga keagamaan yang melakukan rekayasa sosial (social engineering). Menilik proses perubahan yang terjadi di pesantren, tampak bahwa hingga dewasa ini, lembaga pesantren telah memberi kontribusi penting dalam penyelenggaraan pendidikan nasional, serta memiliki pengaruh besar dalam kehidupan masyarakat Indonesia.

\section{Pengembangan Sikap dan Amal Keagama- an}

Menurut Umar Hamalik ${ }^{7}$ sikap merupakan tingkat afektif yang positif atau negatif yang berhubungan dengan objek psikologis, positif dapat diartikan senang, sedangkan negatif berarti tidak senang atau menolak. Senada dengan itu Thorstone dalam Saifuddin Azwar ${ }^{8}$ mengatakan bahwa sikap merupakan tingkatan afeksi yang positif dan negatif yang dihubungkan dengan objek psikologik. S.Nasution ${ }^{9}$ mengatakan sikap adalah seperangkat kepercayaan yang menentukan preferensi atau kecendrungan tertentu terhadap suatu objek atau situasi. Menurut Mueller sebagaimana dikutip To-

${ }^{6}$ Zamakhsyari Dhofier.1985. Tradisi Pesantren: Studi tentang Pandangan Hidup Kyai. Jakarta: LP3ES, h. $44-55$

${ }^{7}$ Oemar Hamalik.2009.Psikologi Belajar Mengajar. Bandung: Sinar Baru, h.214

${ }^{8}$ Saifuddin Azwar. 1888. Sikap Manusia Teori dan Pengukurannya. Yokyakarta: Liberty,h. 3

${ }^{9}$ S.Nasution., 2009. Kurikulum dan Pengajaran. Jakarta: Bumi Aksara, h.133 
hirin ${ }^{10}$ sikap adalah menyukai atau menolak suatu objek.

Dari beberapa pernyataan di atas menunjukkan bahwa, pada prinsipnya sikap adalah kecenderungan individu (siswa, murid atau santri) untuk bertindak dengan cara tertentu, apakah dalam bentuk kecenderungannya untuk berperilaku dalam bentuk menerima, maka mereka mencintai dan selalu ingin untuk berbuat, atau kecenderungan untuk membenci maka ia akan menolak dan selalu untuk menghindari. Sikap tersebut bisa terbentuk dalam perkembangan individu, sikap dapat dipelajari dan dapat berubah-rubah. Sikap merupakan hasil belajar yang diperoleh melalui pengalaman, keteladanan, pembiasaan, penciptaan suasana keagamaan yang Islami.

Sedangkan amal, menurut Atabik Ali dan Ahmad Zuhdi Muhdlor ${ }^{11}$ berarti "berbuat, mengerjakan, melakukan". Amal keagamaan adalah perbuatan yang dilakukan dengan motivasi agama serta dibenarkan atau tidak dilarang oleh agama. Pengamalan agama meliputi pengamalan ritual dan non-ritual atau ibadah khashah dan ibadah 'aamah. Menurut Zakiah Daradjat ${ }^{12}$ Ibadah khashah ialah ibadah yang ketentuannya telah ditetapkan oleh nash, seperti: shalat, puasa, zakat, dan haji. Ibadah 'aamah, ialah semua pernyataan baik, yang dilakukan dengan niat yang baik dan semata-mata karena Allah, seperti: makan dan minum, serta segala pekerjaan yang dilakukan oleh seorang muslim dengan niat karena Allah serta tidak dilarang oleh agama. Dengan demikian dapat dipahami amal keagamaan adalah tindakan, keterampilan atau kemampuan dalam melakukan, melaksanakan, mempraktekkan ajaran agama Islam

10 Mueller dalam Tohirin. 2006. Psikologi Pembelajaran Pendidikan Agama Islam. Jakarta: Raja Grafindo Persada, h. 98

${ }^{11}$ Atabik Ali dan Ahmad Zuhdi Muhdlor.1998. Kamus Kontemporer.Arab Indonesia. Yokyakarta: Penerbit Grafika,h.1322

${ }_{12}$ Zakiah Daradjat. 1995. Ilmu Figh. Jakarta: Dana Bhakti Wakaf, h. 3 terutama dalam bentuk ibadah, pelaksanaannya dilakukan secara konsisten, terus menerus dan benar serta dengan niat ikhlas karena Allah SWT.

\section{METODE PENELITIAN}

\section{Jenis Penelitian}

Penelitian ini bercorak field research dengan jenis kualitatif, dimulai dari lapangan yakni berdasarkan fakta empiris, dari sini melahirkan logika-logika berfikir induktif, dimana sillogisme dibangun berdasarkan pada hal-hal khusus atau data di lapangan dan bermuara pada hal-hal yang umum ${ }^{13}$ dari lapangan sendiri akan dibangan dan dikembangkan. Metode kualitatif akan menghasilkan data deskriptif berupa katakata tertulis atau lisan dari orang-orang dan perilaku yang dapat diamati yang diungkap secara holistik (utuh). ${ }^{14}$ Menurut Winarno Surakhmad ${ }^{15}$ metode diskriptif tidak terbatas hanya sampai pada pengumpulan dan penyusunan data, tetapi meliputi analisis dan interpretasi tentang arti data tersebut. Pada penelitian ini antara deskripsi dan analisis akan dilakukan sejalan secara bersamaan. Hal ini ditelaah satu persatu, serta ditanya mengapa, alasan apa dan bagaimana terjadinya dan peneliti tidak menganggap bahwa sesuatu yang terjadi memang sudah demikian keadaannya.

\section{Pendekatan Penelitian}

Penelitian ini menggunakan pendekatan naturalistik, yaitu pendekatan penelitian yang menjawab permasalahan, memerlukan pemahaman secara mendalam dan menyeluruh mengenai objek yang diteliti guna menghasilkan kesimpulan-kesimpulan

${ }^{13}$ Burhan Bungin. 2001. Metodologi Penelitian Kualitatif. Jakarta: Raja Grafindo Persada,h.66

${ }^{14}$ Lexy J. Moleong. 2007. Metodologi Penelitian Kualitatif. Bandung: Remaja Rosda Karya, h. 4.

${ }^{15}$ Winarno Surakhmad. 1978. Dasar dan Teknik Research, Pengantar Metodologi Ilmiyah. Bandung: Tarsito, h. 131 
penelitian dalam konteks waktu dan situasi yang bersangkutan. ${ }^{16}$ Melalui pendekatan naturalistik ini peneliti berperan sebagai $h u$ man instrument, sekaligus berfungsi sebagai "alat penelitian". Objek yang diteliti tidak lepas dari konteks waktu/situasi, sehingga penelitian cendrung berlangsung dalam setting/lingkungan nyata yang alamiah (natural).

\section{Informan dan Teknik Pengumpulan Data}

Informan utama dalam penelitian ini terdiri dari: Ketua Yayasan Sekolah Pendidikan Islam Indonesia (SPPI), Pimpinan Ponok Pesantren, Pendidik (Buya, guru, ustadz), Kepala Asrama, Ketua Komite Pesantren dan santri. Sedangkan informan pendukung, yaitu Kasi Peka Pontren, Kepala Kantor Kementerian Agama, dan dokumentasi. Pengambilan sampel dilakukan dengan menggunakan teknik snow ball sampling (sampel bola salju). Informan pertama dimulai dari pimpinan Pondok Pesantren, informan berikutnya ditentukan berdasarkan informasi dari informan pertama dan seterusnya, sejak informan utama sampai informan pendukung. Ini dilakukan dalam upaya mencari titik temu suatu permasalahan di lapangan sampai titik jenuh. Pengumpulan data dilakukan melalui teknik: (1) observasi partisipan atau pengamatan berperan, yang mana peneliti dalam melakukan observasi memainkan peranan sebagai partisipan atau peserta dalam tiap-tiap kegiatan sosial keagamaan, terutama terhadap kegiatan yang berkaitan dengan fokus penelitian; (2) wawancara mendalam atau wawancara bebas untuk mendapat data yang lebih luas dan spontan serta mendapatkan informasi yang selengkap dan sedalam mungkin; (3) dokumentasi terutama untuk memperoleh data pendukung berupa struktur organisasi, keadaan pendidik, pegawai, santri, sarana dan prasarana serta kurikulum yang digunakan.

${ }^{16}$ Nana Sujana dan Ibrahim. 2004. Penelitian dan Penilaian Pendidikan. Bandung: Sinar Baru Al-Gensindo, h. 6

\section{HASIL DAN PEMBAHASAN}

Penelitian ini menghasilkan model yang diberi nama "Model Pengembangan Sikap dan Amal Keagamaan Santri", secara rinci model yang ditawarkan meliputi halhal sebagai berikut:

\section{Rasional}

Tujuan pendidikan menurut Undang Undang Sistem Pendidikan Nasional No. 20 tahun 2003 pasal 3 menyebutkan, Pendidikan Nasional bertujuan untuk berkembangnya potensi, peserta didik agar menjadi manusia yang beriman dan bertakwa kepada Tuhan Yang Maha Esa, berakhlak mulia, cakap, kreatif, mandiri, dan menjadi warga negara yang demokratis serta bertanggung jawab. Bersamaan dengan ini pendidikan Islampun bertujuan melahirkan manusia yang beriman dan bertakwa terhadap Allah SWT dan berakhlak mulia. Begitu juga Pesantren Nurul Haq bertujuan untuk mempersiapkan kader-kader ulama yang mandiri, kreatif dan inovatif. Semua komponen pesantren mendukung dalam pelaksanaan proses pendidikan seperti pelaksanaan administrasi dan supervisi pendidikan, kurikulum pengajaran, seyogyanya bermuara pada tujuan pendidikan yang telah dirumuskan oleh Yayasan Sekolah Pendidikan Islam Indonesia (S.P.I.I.) bersama dengan Kepala/pimpinan Pondok Pesantren Nurul Haq.

Dari kenyataan yang peneliti temui tampaknya belum semua program dan kegiatan yang ada di Pondok Pesantren Nurul Haq telah mengarah pada upaya untuk mengembangkan sikap dan amal keagamaan. Program pengembangan sikap dan amal keagamaan adalah salah satu programprogram yang menunjang untuk mencapai tujuan yang telah dirumuskan. Berdasarkan bentuk kegiatan yang telah dilaksanakan untuk mengembangkan sikap dan amal keagamaan memerlukan model yang lebih cocok, oleh karena itu peneliti merasa perlu 
untuk merumuskan suatu model yaitu model berorientasi pada pengembangan sikap dan amal keagaman santri.

\section{Landasan Filosofis}

Dalam rangka meningkatkan efisiensi, motivasi belajar aktif dan kreatif, berorientasi pada peserta didik, memandu agar belajar lebih baik, terutama dalam mengembangkan sikap dan amal keagamaan santri, model ini sangat menarik, mengingat kondisi sekarang pengembangan sikap dan amal keagamaan sangat penting. Jika kita lihat pada intinya manusia itu diciptakan Allah yang terdiri dari berbagai unsur yang menjadi suatu kesatuan utuh yang tidak terpisah, seperti unsur jasmani rohani, fisik psikis, material spiritual, begitu juga ilmu dan amal. Sebagai hamba Allah yang diciptakan, dia wajib beriman serta mengamalkan dalam bentuk ibadah semata-mata karena Allah. Sebagai manusia ia akan mempertanggungjawabkan segala perbuatannya di dunia dan akhirat.

\section{Visi}

Model pengembangan sikap dan amal keagamaan santri adalah mengembangkan kaderisasi ulama dengan kompetensi mengaktualisasikan ilmu-ilmu keislaman yang tercermin dalam pengembangan sikap dan amal keagamaan. Mengimplementasikan fungsi khalifah Allah di muka bumi yang tercermin dalam sikap proaktif, inovatif dan kreatif.

\section{Misi}

Visi model pengembangan sikap dan amal keagamaan santri di Pondok Pesantren Nurul Haq mengembankan misi: a) Membina dan mengembangkan santri memiliki aqidah yang benar dan sikap menerima Islam sebagai agama yang benar pula, b) Meningkatkan amal ibadah dan akhlak yang mulia, c) Meningkatkan daya berfikir dan berzikir dalam upaya mencip- takan "Insan Kamil" yang paripurna yaitu manusia yang mengimbangkan antara kecerdasan akal (IQ), kecerdasan spiritual (SQ) dan kecerdasan agama (RQ) yang melahirkan ilmu yang amaliah dan amal yang ilmiah dan d) Meningkatkan sumber daya pendidikan secara kuantitatif dan kualitatif untuk mewujudkan santri yang bermutu.

\section{Tujuan}

Tujuan umum model pengembangan sikap dan amal keagamaan santri adalah agar lulusannya memiliki hal-hal sebagai berikut:

a. Memiliki aqidah yang benar dan sikap menerima Islam sebagai agama yang benar:

1) Santri terbiasa berdo'a dulu kepada Allah SWT. setiap akan memulai suatu pekerjaan,

2) Santri terbiasa memuji Allah apabila melihat sesuatu yang ia kagumi,

3) Santri terbiasa merenungkan keagungan Allah dengan melihat ciptaan-Nya melalui indera dan hati yang diberikan-Nya,

4) Santri percaya kepada rukun iman yang enam, yaitu percaya kepada Allah SWT., kepada Malaikat, kepada Rasul, kepada Kitab, kepada Hari Akhirat, Qadla dan Qadar.

b. Meningkatkan amal ibadah dan akhlak mulia:

1) Santri terbiasa beramal kepada Allah SWT tanpa diperintah oleh guru dan orang tua,

2) Santri mampu mencontoh perkataan dan perbuatan (sunnah) Rasulullah SAW dalam kehidupan sehari-hari,

3) Santri menghilangkan rasa dendam, dapat menepati janji, berperilaku jujur, berbuat baik kepada orang lain secara ikhlas, dan 
4) Santri peduli terhadap orang lain dengan mempererat ukhuwah Islamiyah, peduli sosial dengan tolong menolong, dan peduli lingkungan dengan menjaga kebersihan dan kelestariannya.

c. Meningkatkan daya berfikir dan berzikir:

1) Santri dapat menggunakan sarana akal untuk berfikir, berfikir positif, berfikir kritis terutama pada aspek ilmu, yang berhubungan hal yang konkrit.

2) Santri dapat menggunakan kalbu untuk berzikir, terutama dalam menghayati dan membesarkan serta mendekatkan diri pada Allah SWT.

3) Santri dapat menjalankan agama dengan benar sesuai dengan tuntunan yang telah ditetapkan.

d. Meningkatkan sumber daya pendidikan baik secara kuantitatif maupun kualitatif:

1) Santri merupakan sumber daya pendidikan yang menjadi harapan buat masa depan dalam menghadapi zaman yang memiliki daya saing yang lebih kompetitif,

2) Santri dapat meningkatkan kualitas dirinya melalui jalur pendidikan formal maupun non formal.

\section{Kurikulum}

Kurikulum yang dilaksanakan pada Pondok Pesantren Nurul Haq merupakan perpaduan antara kurikulum Kementerian Pendidikan Nasional, kurikulum Kementerian Agama dan Kurikulum Yayasan Sekolah Pendidikan Islam Indonesia Kerinci yang dipadukan dalam satu rumusan iman, ilmu dan amal. Pengembangan sikap dan amal keagamaan terintegrasi antara kurikulum nasional dan kurikulum pesantren. Materi Pelajaran Agama Islam diperluas dengan pengajaran tilawah Al-Qur'an (tajwid), tahfidz ayat-ayat Al-Qur'an, hadits dan do'a, shalat berjamaah, kajian Al-Quran, Tarbiatul Muballiqin, pelajaran bahasa Arab (Qiraatul Qutub), serta muhadharah, cerdas cermat, Yasinan. Guru/ustadz pembimbing dalam melaksanakan tugasnya harus sesuai dan sejalan dengan kurikulum yang berlaku di Madrasah Nurul Haq.

\section{Personalia}

Personalia untuk pelaksanaan model pengembangan sikap dan amal keagamaan di Pondok Pesantren Nurul Haq antara lain sebagai berikut: a) Kepala/Pimpinan sebagai koordinator, b) Guru mata pelajaran Pendidikan Agama Islam pada Pesantren, c) Ustadz pembimbing mata pelajaran $\mathrm{Ku}-$ rikulum Pesantren, d) Ustadz pembimbing Asrama, dan e) orang tua santri. Dalam pelaksanaan model pengembangan sikap dan amal keagamaan ini semua personalianya selalu mengikuti norma yang sesuai dengan ajaran agama Islam.

\section{Fungsi}

Fungsi model pengembangan sikap dan amal keagamaan santri di Pesantren Nurul Haq adalah membantu santri agar berperilaku amar makruf nahi munkar (mengajak berbuat baik dan melarang berbuat kejahatan), bersikap positif dalam beriman, bertakwa dan berakhlak serta mengamalkan setiap perintah yang terdapat dalam ajaran Islam.

\section{Fasilitas}

Berbagai fasilitas yang dipelukan dalam penerapan model pengembangan sikap dan amal keagamaan santri di Pesantren Nurul Haq Kerinci antara lain sebagai berikut: a) ruangan untuk koordinator bimbingan ibadah, $b$ ) ruangan untuk guru/ustadz pembimbing ibadah, c) ruangan untuk kegiatan bimbingan ibadah, d) ruangan data santri, e) ruangan tamu, f) yang ter- 
penting ada untuk model pengembangan sikap dan amal keagamaan, adalah masjid tempat santri dan personil lainnya dapat menunaikan ibadah, terutama shalat, praktik dakwah, dan lainnya. Semua ruangan tersebut dilengkapi dengan perabot, alat dan bahan sesuai dengan kegiatan yang akan dilakukan.

\section{Upaya Pengembangan}

Upaya pengembangan sikap dan amal keagamaan dilakukan oleh guru Pendidikan Agama Islam atau ustadz pada Pesantren Nurul Haq, secara umum terhadap seluruh santri, secara khusus sesuai dengan kebutuhan santri secara kelompok, serta secara perorangan. Upaya pengembangan dilakukan sesuai dengan kebutuhan semua santri, kelompok santri maupun secara perorangan, Upaya pengembangan, selalu berhubungan dengan konsep sikap dan amal keagamaan yang didasari ajaran Islam. Guru/ustadz secara umum melaksanakan bimbingan kepada semua santri, yang berhubungan dengan sikap keagamaan dan amal keagamaan. Di samping itu juga dilakukan secara kelompok maupun secara perorangan, agar masing-masing santri benar-benar dapat bersikap positif terhadap agama dan bisa mengamalkan semua ajaran dengan baik dan sempurna. Upaya pengembangan sikap dan amal keagamaan juga dilakukan dengan kerja sama dengan personil pesantren lainya, seperti dengan guru mata pelajaran, wali kelas, dan orang tua santri.

\section{Kriteria Keberhasilan}

Kriteria keberhasilan pelaksanaan pengembangan sikap dan amal keagamaan santri, adalah santri mampu melakukan berbagai macam ibadah baik ibadah khash maupun ibadah 'am, yang merupakan hubungan vertikal dengan Allah (habl min Allah) dan hubungan horizontal dengan sesama manusia ( habl min Nash ). Di samping mampu mengembangkan sikap yang baik dalam kehidupan dan beramal, santri mampu mendakwahkannya kepada orang lain, menjadi pendorong dalam beramal, serta mampu mempersiapkan diri untuk mengikuti pendidikan selanjutnya.

\section{Langkah-langkah dalam Pengembangan Sikap dan Amal Keagamaan Santri.}

\section{Melalui Kurikulum Nasional dan Kuriku- lum Pondok Pesantren;}

Pertama, melalui pribadi: pengembangan sikap dan amal keagamaan santri di Pesantren Nurul Haq bertujuan untuk membantu santri mengenal, menemukan, dan mengembangkan pribadi muslim mencakup pengembangan sikap beriman dan bertakwa serta beribadah kepada Allah SWT secara mandiri.

Kedua, melalui kelompok/sosial: pengembangan sikap dan amal keagamaan santri di Pesantren Nurul Haq bertujuan membantu santri dalam kaitannya dengan kelompok atau lingkungan sosial dan etika pergaulan antara sesama santri dengan cara meningkatkan ukhuwah Islamiyah, meningkatkan sillaturrahim, tolong menolong, menjunjung tinggi tata krama, sopan santun, serta nilai-nilai agama, adat dan kebiasaan yang berlaku di tengah masyarakat.

Ketiga, melalui pembelajaran: pengembangan sikap dan amal santri di Pesantren Nurul Haq bertujuan untuk mengenal, menumbuhkan dan mengembangkan diri, sikap dan kebiasaan belajar yang inovatif dan kreatif untuk mengembangkan sikap dan amal keagamaan. Selalu memupuk kemauannya untuk melanjutkan pendidikan ke tingkat pendidikan yang lebih tinggi. Pengembangan sikap kebiasaan yang baik dalam mencari informasi dari berbagai sumber, bersikap positif kepada guru/ ustadz dan staf yang terkait, mau dan senang mengerjakan tugas, mengembangkan keterampilan belajar, belajar dengan kreatif dan inovatif, menjalani program penilaian, serta program perbaikan dan 
pengayaan, menumbuhkan disiplin belajar dan berlatih, baik secara mandiri maupun kelompok, mengembangkan penguasaan materi program belajar di Pesantren Nurul Haq. Melalui kurikulum nasional kendatipun terlihat lebih banyak porsi kognitif dibanding aspek afektif/sikap dan psikomotorik/amal, namun ini disempurnakan atau dikembangkan melalui kurikulum pesantren, dengan demikian santri dapat bersikap positif terhadap agama, serta mau dan dapat mengamalkan dalam kehidupan sehari-hari.

\section{Melalui Berbagai Pendekatan:}

1. Pendekatan Pengalaman

a. Dalam proses pembelajaran di dalam kelas. Guru/ustadz melakukan pengembangan sikap dan amal keagamaan secara induvidu. Pada individu disuruh belajar sendiri untuk mencari pengalaman, dia dapat melakukan seleksi serta menentukan sendiri apakah yang dilakukannya itu positif atau negatif, dari sekian banyak yang dipelajarinya ada yang berhasil dan menyenangkan baginya dan ada pula yang gagal atau menyebabkan dirinya mendapat hukuman. Individu disuruh belajar melalui proses trial and error dalam rangka memilih respons yang tepat bagi stimulus tertentu. Pada awalnya individu bisa saja salah dalam bersikap dan beramal, namun dengan pengalamannya mencoba terus menerus, akhirnya kesalahan akan semakin kurang dan akhirnya semakin sempurna. Di samping individu juga dilakukan melalui kelompok, santri dibagi kepada beberapa kelompok untuk belajar menurut pengalamannya masingmasing, mereka melakukan diskusi kelompok, dan akhirnya tiap ke- lompok dipertemukan lalu diambil suatu kesepakatan.

b. Dalam proses pembelajaran di luar kelas. Usaha pengembangan amal keagamaan santri dengan mengikutsertakan santri dalam mempraktekkan segala bentuk ibadah sejak bersuci, berwudhu', gerakangerakan dan bacaan shalat, tata cara shalat Jum'at dan khutbah, dan shalat-shalat sunat lainnya. Kemudian para santri melakukan sendiri secara terus menerus dan akhirnya menjadi pengalaman yang berharga dan sulit untuk ditinggalkan.

2. Pendekatan Keteladanan. Belajar melalui proses peniruan dilakukan di Pesantren Nurul Haq, dilakukan: Pertama dengan menampilkan dirinya sebagai sosok yang pantas untuk diteladani, mulai dari Kepala/pimpinan pesantren, para guru/ustadz dan tenaga kependidikan lainnya. Kedua, dengan menampilkan perilaku orang lain yang kemudian dijadikan pedoman untuk diteladani dan ditampilkan oleh dirinya, seperti: keteladanan Nabi $\mathrm{Mu}$ hammad dengan kesempurnaan budi pekerti, kesempurnaan tutur kata dan kesempurnaan perbuatan. Keteladanan Khulafaurrasyidin dan kesempurnaan sebagian Khalifah Muawiyah dan Abbasiyah.

\section{Pendekatan Pembiasaan}

a. Pembiasaan dalam melaksanakan ibadah mahdah. Pesantren Nurul Haq membiasakan santri dalam melaksanakan ibadah mahdah seperti shalat wajib dengan cara mengontrol para santri pada awal waktu untuk melaksanakan shalat pada awal waktu dan secara berjamaah, dengan kontrol yang rutin akhirnya para santri terbiasa melakukan shalat tersebut, dan begitu juga terhadap puasa wajib. Sedangkan terhadap shalat sunat dan 
puasa sunat, pimpinan pesantren beserta guru/ustadz senior melalui pendekatan pembiasaan dengan melakukan beberapa shalat sunat dan puasa sunat yang mudah dikontrol seperti shalat rawatib, shalat tahiyatul masjid, shalat tarawih dan witir dan lainnya, begitu juga terhadap puasa sunat, seperti puasa Senin dan Kamis, puasa Arafah, puasa hari Asyura 10 Muharam dan lainnya.

b. Pembiasaan dalam melaksanakan ibadah ghairu mahdah. Pesantren Nurul Haq melaksanakan pembiasaan dalam ibadah ghairu mahdah dengan cara menjaga persatuan, ketertiban, kedisiplinan, dengan melakukan Apel Bendera tiap hari Senin, memelihara ukhuwah Islamiyah, dengan melaksanakan Yasinan tiap hari Jum'at, sekaligus melaksanakan gotong royong untuk membersihkan lingkungan. Sedangkan dalam kehidupan di asrama, para santri terbiasa mengembangkan sikap saling tolong menolong, selalu bersilaturrahim, selalu menunjukkan akhlak terpuji kepada sesama teman, menunjukkan kejujuran, saling memaafkan, sehingga suasana asrama menjadi kondusif, aman dan tertib.

c. Pendekatan Emosional berupaya menggugah emosi santri dalam meyakini, memahami dan menghayati ajaran agama. Melalui pendekatan ini santri dilatih untuk mengembangkan perasaan keagamaan sedemikian rupa sehingga bertambah kuat keyakinannya.

d. Pendekatan Simulasi yaitu menunjukkan pelaksanaan dari ajaran (ibadah) dalam Islam seperti bagaimana praktek shalat, bagaimana praktek menghormati masjid, bagaimana praktek berhubungan baik dengan sesama, praktek hormat kepada orang yang lebih tua dan lain-lain.

e. Pendekatan Targhib dan Tarhib. Pertama Targhib, Dalam upaya pengembangan sikap dan amal santri, Pesantren Nurul Haq beserta dengan para guru dan pimpinan asrama telah menerapkan targhib/ reward terhadap para santri yang memiliki motivasi belajar tinggi serta telah berprestasi dalam berbagai macam kegiatan baik yang berhubungan dengan kegiatan kurikuler, co-kurikuler maupun ektrakurikuler. Targhib diberikan pada tiap akhir semester, waktu naik kelas, maupun sesudah selesai kegiatan dilaksanakan, yang diberikan dalam bentuk hadiah atau penghargaan. Targhib bertujuan untuk meningkatkan prestasi, atau mempertahankan prestasi yang pernah diperoleh. Dalam proses belajar targhib/reward atau reinforcement (penguatan) menjadi faktor penting dalam teori ini, karena perangsang itu memperkuat respons yang telah dilakukan, asal saja tidak dilakukan terlalu sering, karena bisa mengubah perilaku untuk selalu menunggu hadiah, kalau tidak ada hadiah tidak mau belajar. Kedua Tarhib, dalam pengembangan sikap dan amal keagamaan santri. Pesantren Nurul Haq beserta para guru/ustadz memberikan tarhib/punishment terhadap santri yang melakukan pelanggaran terhadap ketentuan atau peraturan yang beraku. Tarhib bertujuan untuk menjerakan santri agar tidak mengulangi perbuatannya. Jenisjenis hukuman yang diberikan terdiri dari: Hukuman ringan yaitu membersihkan kantor, lokal, masjid dan halaman, atau yang seimbang dengan itu. Hukuman sedang 
yaitu membersihkan kebun, kamar mandi/WC, atau yang seimbang dengan itu. Hukuman berat yaitu dipindahkan, diberhentikan (dipulangkan ke orang tua).

4. Melalui Penciptaan Suasana Keagamaan. Pengembangan sikap dan amal keagamaan santri melalui penciptaan suasana keagamaan dilakukan dengan:

1) Bentuk Struktural yang bersifat topdown, yaitu kebijakan kepala MTsS dan pimpinan pesantren membuat aturan-aturan yang dijadikan pedoman dalam upaya pengembangan sikap dan amal keagamaan santri. Seperti menetapkan jadwal yang tidak bertabrakan dengan jadwal shalat, menetapkan pakaian sekolah dan harian yang Islami dan melakukan berbagai kegiatan yang bersifat Islami.

2) Bentuk Formal memberikan mata pelajaran agama dengan memasukkan nuansa Islam pada mata pelajaran umum, semacam Islamisasi mata pelajaran.

3) Bentuk Mekanik Pendidikan dipandang sebagai penanaman dan pengembangan seperangkat nilai kehidupan, masing-masing bergerak berjalan menurut fungsinya. Dengan demikian diharapkan fungsi sikap dan amal dapat dikembangkan.

4) Bentuk Organik menerapkan kurikulum umum yang berkorelasi dengan nilai-nilai Islam, dengan mencari ayat-ayat yang berhubungan dengan materi yang dibahas.

Sebagai langkah-langkah pelaksanaannya, dapat dilihat diagram deskripsi model pengembangan sikap dan amal keagamaan santri.

\section{DIAGRAM PENGEMBANGAN SIKAP DAN AMAL KEAGAMAAN}

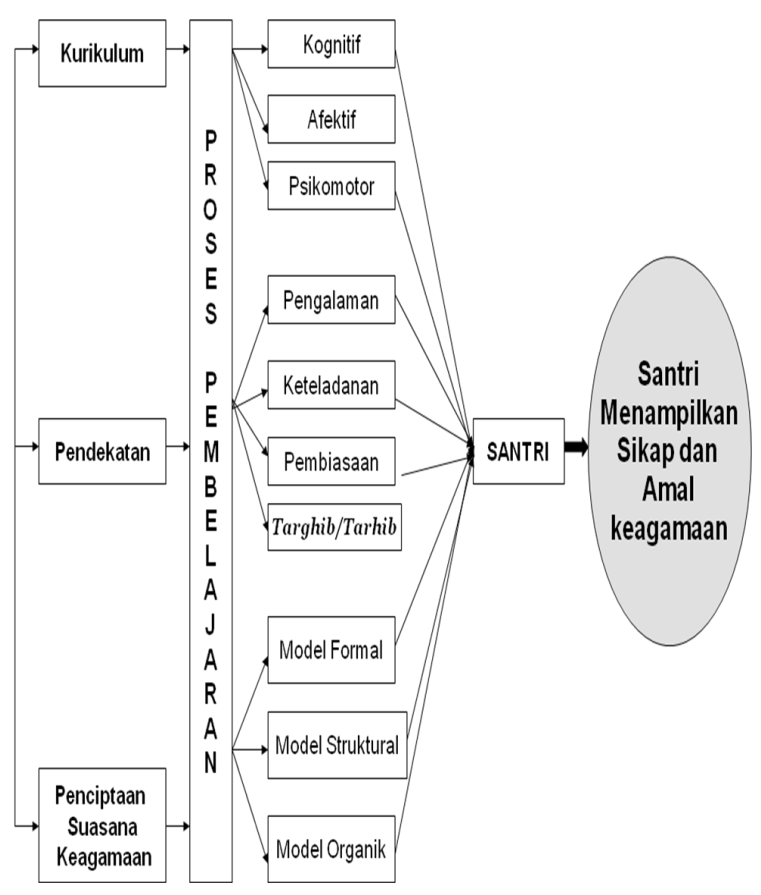

Kualifikasi Personil Pengembang Sikap dan Amal Keagamaan

Kualifikasi personil pengembang sikap dan amal yang diharapkan untuk mengembangkan sikap keagamaan pada santri, antara lain seperti berikut.

a. Pengetahuan dan Pengamalan Ajaran Agama Islam. Guru/ustadz diharapkan memahami dan mengamalkan ajaran agama Islam secara "kaffah". Untuk itu, sikap, perilaku, perkataan, pengamalan harus mencerminkan nilai-nilai Islami, memiliki pengalaman yang luas dalam beragama, dapat menjadi suri tauladan yang baik bagi santri, dan sudah terbiasa mengamalkan atau beribadah sesuai dengan tuntunan ajaran Islam.

b. Proses Kelompok. Guru/ustadz harus paham dan terampil dalam pembentukan kelompok dan pembinaan kelompok. Manusia atau santri sebagai makhluk sosial, harus berinteraksi dengan kelompok sosial, dan siswa tidak boleh bersifat individualistis, karena ia 
merupakan sub sistem dari kelompoknya dan merupakan sub sistem dari masyarakat secara luas.. Oleh karena itu, dalam kelompok, ia dapat mendiskusikan berbagai masalah atau soal dan kaitannya dengan pengembangan sikap dan amal keagamaan.

c. Lingkungan Manusiawi. Guru/ustadz perlu memiliki pengetahuan, sikap, dan keterampilan serta dapat menanamkan sikap pada seluruh personil madrasah bahwa: para santri merupakan bagian kelompok manusiawi yang paling penting dan berada dalam lingkungan sosial pada suatu madrasah. Santri memerlukan kerja sama yang baik dengan lingkungan sosialnya, mempergunakan sumber-sumber pendidikan yang tersedia dalam masyarakat, mengembangkan konsep pesantren berbasis masyarakat, sehingga hubungan antara pesantren dengan lingkungan masyarakat dilaksanakan secara totalitas dapat terwujud, dibina dan dikembangkan komunikasi yang tepat dalam berbagai kegiatan pesantren, orang tua dan masyarakat dilibatkan sejak perencanaan, pelaksanaan, serta perbaikan dalam pendidikan.

\section{Prosedur Pelaksanaan Model}

Prosedur pelaksanaan model pengembangan sikap dan keagamaan santri pada Pesantren Nurul Haq Kerinci antara lain sebagai berikut: a. Ustadz/kyai yang mengajar mata pelajaran Pendidikan Agama Islam mengindentifikasi materi yang berhubungan dengan sikap keagamaan dan amal keagamaan, b. Memberitahukan kepada ustadz/kyai pesantren materi-materi yang dianggap belum tuntas diberikan karena keterbatasan waktu, c. Ustadz/kyai mendalami materi tersebut melalui kurikulum pesantren, d. Ustadz/kyai membimbing santri untuk percaya dan bersikap positif terhadap ajaran Islam dengan menunjukkan dalil Al Qur'an dan sunnah
Rasul, e. Para santri diminta percaya, mentaati yang berhubungan dengan sikap dan mengamalkan yang berhubungan dengan ibadah, f. Ustadz/kyai selalu mengontrol agar sikap dan amal keagamaan betul-betul dapat diimplementasikan oleh santri dalam kehidupan sehari-hari.

\section{Evaluasi Pelaksanaan Model}

Evaluasi pelaksanaan model ditekankan pada evaluasi proses dan pelaksanaan dengan pemberdayaan personil madrasah lainnya maupun proses manajemen pengembangan sikap dan amal keagamaan. Evaluasi dapat juga dilaksanakan melalui pengamatan terhadap subyek yang dievaluasi, dengan cara melakukan pengamatan terhadap santri yang berhubungan dengan sikap dan amal keagamaan, apakah santri menerima, meyakini dan menganggap positif atau menolak, mengingkari dan menganggap negatif. Jika menerima, meyakini dan menganggap positif, maka ia akan mengamalkan, jika ia menolak, mengingkari atau menganggap negatif, maka ia akan meninggalkan atau tidak mengamalkan.

\section{Dukungan Sistem}

Pengembangan sikap dan amal keagamaan santri pada Pondok Pesantren Nurul Haq perlu mendapat dukungan sistem, antara lain dalam hal berikut.

a. Sistem Manajemen dan Operasional. Berbagai aspek manajemen dan operasional yang meliputi: (a) peran, tugas, dan tanggung jawab kepala/ pimpinan pesantren, wali kelas, guru mata pelajaran, pembimbing asrama, dan personil Madrasah lainnya (b) pengembangan mekanisme kerja, sistem informasi dan monitoring, supervisi, dan evaluasi, serta (c) pengembangan perangkat operasional administrasi. Seperti pembenahan ruangan praktik ibadah, penyusunan jadwal kegiatan 
ektrakurikuler yang mendukung pengembangan sikap dan amal keagamaan, perintisan komputerisasi data mu$\mathrm{rid} /$ santri, dan penyusunan struktur organisasi penanggung jawab.

b. Pengembangan Program. Pengembangan program pengembangan sikap dan amal keagamaan santri pada Pesantren Nurul Haq Kerinci berdasarkan kondisi yang ada di pesantren. Program tersebut disusun terkoordinasi dan terintegrasi dengan keseluruhan program pendidikan di pesantren. Semua komponen pesantren mendukung dan mengembangkan dalam bentuk kesatuan visi, dalam jangka waktu tidak terbatas, sehingga menjadi ciri khas pesantren, serta para lulusannya dapat pula mengembangkannya pada tempat mereka masing-masing.

c. Pemanfaatan Sumber Daya Masyarakat. Pelaksanaan model pengembangan sikap dan amal keagamaan santri ini memerlukan kerjasama dengan unsurunsur yang ada dalam masyarakat, sehingga dapat menjadi faktor pendukung dalam pengembangan sikap dan amal santri. Unsur masyarakat yang potensial menjadi sumber daya pendukung pelaksanaan pengembangan sikap dan amal keagamaan santri antara lain: Kementerian Agama Kabupaten, Kementerian Pendidikan Nasional, MUI, DDII, PGRI dan organisasi keagamaan lainnya.

Syarat yang diperlukan untuk Mentransfer Model Pengembangan Sikap dan Amal Keagamaan Ke Madrasah/Pesantren lain

Model pengembangan sikap dan amal keagamaan dapat dilaksanakan dan ditransferkan ke Madrasah/Pesantren lain, dengan syarat sebagai berikut:

a. Tujuan pendidikan sesuai dengan tujuan pendidikan Islam

b. Kualifikasi kemampuan guru c. "Lingkungan" (personil madrasah yang terkait) perlu pemberdayaan

d. Tersedianya fasilitas yang memadai untuk pelaksanaan model pengembangan sikap dan amal keagamaan.

e. Program disusun terkoordinasi dan terintegrasi dengan keseluruhan program pendidikan di madrasah.

f. Pelaksanaan model pengembangan sikap dan amal keagamaan ini memerlukan kerja sama dengan personil madrasah lainnya, (seperti guru mata pelajaran, wali kelas, kepala sekolah, pustakawan) dan unsur-unsur yang ada dalam masyarakat, sehingga merasa bertanggung jawab dalam peningkatan mutu madrasah.

g. Adanya dukungan dari unsur masyarakat, pemerintah, dan organisasi profesi yang potensial menjadi sumber daya pendukung pelaksanaan, antara lain: Kantor Kementerian Agama Kabupaten, Kementerian Pendidikan Nasional. MUI, DDII, PGRI dan Organisasi Islam lainnya.

h. Evaluasi pelaksanaan model ini ditekankan pada evaluasi proses dan hasil pelaksanaan kegiatan, mulai dari: (a) persiapan kegiatan, (b) pelaksanaan kegiatan, (c) evaluasi kegiatan, (d) analisis hasil evaluasi kegiatan, dan (e) tindak lanjut kegiatan.

Model Pengembangan Sikap dan Amal Keagamaan, merupakan model yang dikembangkan serta telah diseminarkan, didiskusikan (focus group discussion) dengan guru/ustadz Pesantren Nurul Haq bersama beberapa dosen STAIN Kerinci yang menekuni bidang pendidikan Islam.

\section{KESIMPULAN}

Upaya pengembangan sikap dan amal keagamaan telah dilaksanakan dengan sistem belajar sepanjang hari (full day school) melalui pendekatan: pertama pengalaman, 
baik dalam proses pembelajaran maupun dengan mengikut sertakan santri dalam kegiatan ibadah. Kedua keteladanan, dengan menunjukkan sikap yang bisa untuk diteladani, dicontoh. Ketiga pembiasaan, dengan membiasakan diri dalam melaksanakan bermacam ibadah. Keempat targhib dan tarhib, dengan memberi hadiah kepada yang berprestasi dan hukuman kepada yang melakukan pelanggaran, dan dengan penciptaan suasana keagamaan, dengan menerapkan bentuk formal, bentuk struktural dan bentuk organik, namun karena belum ada pola sebagai acuan, kurang komitmen serta belum terpenuhinya kualifikasi personalia, masih terbatasnya fasilitas, sehingga pelaksanaan dan hasil pengembangan sikap dan amal keagamaan belum tercapai dengan sempurna.

Model pengembangan sikap dan amal keagamaan santri yang ditawarkan meliputi aspek sebagai berikut: 1. Rasional, 2. Landasan Filosofis, 3. Visi, 4. Misi, 5. Tujuan, 6. Kurikulum, 7. Personalia, 8. Fungsi, 9. Fasilitas, 10. Upaya Pengembangan, 11. Kriteria Keberhasilan, 12. Langkah-langkah Pengembangan Sikap dan Amal Keagamaan Santri, 13. Kualifikasi Personil Pengembangan Sikap dan Amal Keagamaan, 14. Prosedur Pelaksanaan Model, 15. Evaluasi Pelaksanaan Model, 16. Dukungan Sistem, 17. Syarat yang diperlukan untuk Mentransfer Model Pengembangan Sikap dan Amal Keagamaan ke Pesantren lain.

\section{SUMBER BACAAN}

Ali, Atabik dan Ahmad Zuhdi (1998): Kamus Kontemporer Arab Indonesia. Yokyakarta, Grafika.

Arifin, M. (2003): Ilmu Pendidikan Islam, Tinjauan Teoritis dan Praktis Berdasarkan Pendekatan Interdisipliner. Jakarta, Bumi Aksara.

Azra, Azyumardi (1998): Esai-esai Intelektual Muslim dan Pendidikan Islam. Jakarta, Logos Wacana Ilmu.
Azwar, Saifuddin (1988): Sikap Manusia Teori dan Pengukurannya. Yokyakarta, Liberty.

Bawani, Imam (1987): Segi-segi Pendidikan Islam. Surabaya, Al-Ikhlas.

Bungin, Burhan (2001): Metodologi Penelitian Kualitatif. Jakarta, Raja Grafindo Persada.

Bahri, Syamsul Djamrah dan Aswan Zain, Strategi Belajar Mengajar, Jakarta: Rineka Cipta.

C. P. Chaplin, (terj) Kartini Kartono (1989): Kamus Lengkap Psikologi. Jakarta, Raja Grafindo.

Daradjat, Zakiah (1995): Ilmu Fiqh I. Jakarta, Dana Bhakti Wakaf.

Daien, Amir, Indra Kusuma (1973): Pengantar Ilmu Pendidikan. Surabaya, Usaha Nasional.

Departemen Pendidikan dan Kebudayaan (1995): Kamus Besar Bahasa Indonesia. Jakarta, Balai Pustaka.

Djaali (2008): Psikologi Pendidikan. Jakarta, Bumi Aksara.

Dofier, Zamaksyari (1994): Tradisi Pesantren: Studi Tentang Pandangan Hidup Kyai. Jakarta, LP3ES.

Ensiklopedi Hukum Islam,I, Jakarta: Ichtiar Baru Van Hoeve,1999

Hamalik, Oemar (2009):Psikologi Belajar Mengajar. Bandung, Sinar Baru.

Imam, Sutari Barnadib (1993): Pengantar Ilmu Pendidikan Sistematis. Yokyakarta, Andi Offset.

Jalaluddin (2003): Psikologi Agama. Jakarta, Raja Grafindo.

Ma'sum, Saiful (1994): Menapak Jejak Mengenal Watak. Jakarta.

Moleong,Lexy J. (2007): Metodologi Penelitian Kualitatif. Bandung, Remaja Rosda Karya. 
Mar'at (1982): Sikap Manusia Perubahan Serta Pengukurannya, Jakarta: Ghalia Indonesia.

Mueller dalam Tohirin (2006): Psikologi Pembelajaran Pendidikan Islam. Jakarta, Raja Grafindo Persada.

Muhaimin (2004): Paradigma Pendidikan Islam: Upaya Mengefektifkan Pendidikan Agama Islam di Sekolah. Bandung, Remaja Rosdakarya.

Madjid, Nurcholish (1997): Bilik-bilik Pesantren: Sebuah Potret Perjalanan. Jakarta, Paramadina.

Neviyarni (2009): Pelayanan Bimbingan dan Konseling Berorientasi Khalifah fil Ardh. Bandung, Alfabeta.

Quraish, Muhammad, Shihab (2002): Tafsir Al Misbah. Jakarta, Lantera Hati, vol $11,13$.

(2006): Menabur Pesan Ilahi. Jakarta, Lentera Hati.

Qutb, Muhammad (pen) Salman Harun (1988): Sistem Pendidikan Islam. Jakarta, Al-Ma'arif.

Ramayulis, (2008): Psikologi Agama, Jakarta: Kalam Mulia.

Sa'id, M. Nursi (pen) Al Gazira (2001): Seni Mendidik Anak. Jakarta, Arroyan

al-Sayyid, M. Al-Wakil (1993): Usus Da'wah wa Adab al-Du'ah. Mesir, Dar al-Wafa' / Dar al-Mujtama'.

Syah, Muhibbin (1995): Psikologi Pendidikan: Suatu Pendekatan Baru. Bandung, Remaja Rosdakarya.
Suardiman, Partini S. U. (1984): Psikologi Pendidikan. Yokyakarta, Percetakan Studing.

Sujana , Nana dan Ibrahim (2004): Penelitian dan Penilaian Pendidikan. Bandung, Sinar Baru Al-Gensindo.

S. Nasution (2009): Kurikulum dan Pengajaran. Jakarta, Bumi Aksara.

Surakhmad, Winarno (1978): Dasar dan Teknik Research, Pengantar Metodologi Ilmiyah. Bandung.

Tim Penulis IAIN Syarif Hidayatullah (1992): Ensiklopedi Islam Indonesia. Jakarta, Djambatan,

Utsman, Muhammad, Najati,(pen) Zaenuddin Abu Bakar (2004): Psikologi dalam Perspektif Hadis. Jakarta, Pustaka Al Husna Baru

Usman, Muhammad, Najati, (pen) M. Zaka Al-Farisi (2005): Psikologi dalam AlQur'an. Bandung, Pustaka Setia

Tanlain, Wens. dkk. (1989): Dasar-dasar Ilmu Pendidikan: Buku Panduan Untuk Mahasiswa. Jakarta, Gramedia

Tafsir, Ahmad (2004): Metodologi Pengajaran Agama Islam. Bandung, Remaja Rosdakarya.

(2005): Ilmu Pendidikan Islam dalam Perspektif Islam. Bandung, Remaja Rosdakarya. 